\title{
Linking globalization of entrepreneurship in small organizations
}

\author{
Domingo Ribeiro Soriano $\cdot$ Salvador Roig Dobon
}

Accepted: 30 September 2008/Published online: 20 November 2008

(C) Springer Science+Business Media, LLC. 2008

\begin{abstract}
The field of entrepreneurship spans a wide variety of topic areas, and among the most important is that of the small and medium-sized enterprise (SME). The aim of this paper is to link entrepreneurship and SMEs. Attempting to generalize the outcomes of entrepreneurship in small organizations from different sectors, countries or industries should be activities that are part of daily life on an international scale. In extracting and transferring the outcomes of this research into entrepreneurship and SMEs, policy makers should see an aspect that must be consolidated within the environment of international globalization that surrounds us. It should not be forgotten that what starts out as small (i.e. an SME) can become large over time and this entrepreneurship can form a part of a new organizational structure. A brief overview of the contents of each of the articles included in this special issue on the globalization of entrepreneurship in small organizations is also presented herein.
\end{abstract}

D. R. Soriano · S. R. Dobon

Department of Business Administration,

University of Valencia, Valencia, Spain

D. R. Soriano $(\square)$

Edificio Departamental Oriental, Facultad de Economía de la Universitat de València, Campus de los Naranjos, 46022 Valencia, Spain

e-mail: domingo.ribeiro@uv.es
Keywords Globalization - Entrepreneurship · Small and medium-sized enterprise (SME)

JEL Classifications $\quad$ L25 $\cdot$ L26 $\cdot$ M13 $\cdot$ M16

We were honored when David Audretsch invited us to edit the Journal's 2009 special issue. Like any strategist, we wondered how to deploy this resource in order to create the most value for the field of entrepreneurship in small business in today's globalized world. We want to thank the reviewers who volunteered their time to offer constructive suggestions to refine and improve each article in the issue. We are of course very grateful to the contributing authors.

The link between entrepreneurship and small business, and vice-versa, is a relatively recent one, although studies by Vesper (1974), along with the International Symposium on Entrepreneurship and Enterprise Development that appeared in June 1975, were among the first scientific sources to indicate the presence of such a relationship. In this issue, we analyze the current state of this relationship in the face of new factors that characterize today's international economic climate. The idea that small and medium-sized organizations can adapt more easily to changes in the environment because of their more manageable size, and can compete perfectly with large organizations through specialization and networks provided by new technology, has been widely 
demonstrated in recent years ( $\mathrm{Li}$ and Matlay 2006; Mazzarol and Reboud 2006). Changes that have affected the market and businesses, such as the sweeping tide of globalization, must be analyzed and documented in the near future in order to constitute a guide for researchers, scholars, consultants, entrepreneurs, businessmen, managers, government agencies, policy makers, and practitioners pertaining to a multidisciplinary forum in the field of business.

Small organizations are the most common type of firm found in today's global economy. The current definition of SMEs varies considerably across countries, ranging from enterprises with fewer than 500 employees in some of the most developed countries, such as the United States and Canada, to fewer than 250 employees in the European Union, down to fewer than 100 employees in manufacturing enterprises (and fewer than 50 in non-manufacturing) in Hong Kong, and 50 employees in many developing countries. Porter indicated that the success of SMEs, under the effects of globalization, depended on the formulation and implementation of strategies. Some of these strategies take the form of marketing and innovation. Marketing strategy may be better supported when management has an entrepreneurial bias. Small businesses represent a path towards innovation, as Acs and Audretsch have shown in their extensive research (Acs and Audretsch 1990; Audretsch 1995). Thus, as Schumpeter also pointed out, small organizations are a vehicle for entrepreneurship. Scherer (1988, pp. 45) has summarized the advantages small firms may have in innovative activity: "Smaller enterprises make their impressive contributions to innovation because of several advantages they possess compared to large-size corporations. One important strength is that they are less bureaucratic, without layers of 'abominable no-men' who block daring ventures in a more highly structured organization. Second, and something that is often overlooked, many advances in technology accumulate upon a myriad of detailed inventions involving individual components, materials, and fabrication techniques. The sales possibilities for making such narrow, detailed advances are often too modest to interest giant corporations. An individual entrepreneur's juices will flow over a new product or process with sales prospects into millions of dollars per year, whereas few large corporations can work up much excitement over such small fish, nor can they accommodate small ventures easily into their organizational structures. Third, it is easier to sustain a fever pitch of excitement in a small organization, where the links between challenges, staff, and potential rewards are tight. 'All-nighters' through which tough technical problems are solved expeditiously are common." Jovanovic (2001, pp. 54-55) concludes, "The new economy is one in which technologies and products become obsolete at a much faster rate than a few decades ago...It is clear that we are entering the era of the young firm. The small firm will thus resume a role that, in its importance, is greater than it has been at any time in the last 70 years or so."

Therefore, we can state that the role of entrepreneurship has changed dramatically between the traditional and new economies. The role of SMEs in the post-war economies in North America and Western Europe (Audretsch 2002) showed that: (1) SMEs were generally less efficient than their larger counterparts; (2) SMEs provided lower levels of employee compensation; (3) SMEs were only marginally involved in innovative activities; (4) the relative importance of SMEs was declining over time in both North America and Europe. Conventional wisdom would have predicted that increased globalization would present a more hostile environment to small business (Vernon 1970). Gomez-Casseres (1997, p. 33) further observed that “...students of international business have traditionally believed that success in foreign markets required large size. Small firms were thought to be at a disadvantage compared to larger firms, because of the fixed costs of learning about foreign environments, communicating at long distances, and negotiating with national governments." In most European countries and in North America, SMEs began increasing their relative importance starting in the mid-1970s. With the re-emergence of entrepreneurship as a vital factor, scholars began to look for explanations and to develop a theoretical basis. The early explanations (Brock and Evans 1989) revolved around six hypotheses:

(1) Technological change had reduced the extent of scale economies in manufacturing.

(2) Increased globalization had rendered markets more volatile as a result of competition from a greater number of foreign rivals. 
(3) The changing composition of the labor force towards a greater participation of females, immigrants, and young and old workers may be more conducive to smaller rather than larger enterprises, due to the greater premium placed on work flexibility.

(4) A proliferation of consumer tastes away from standardized mass-produced goods towards stylized, personalized products facilitates a niche for small producers.

(5) Deregulation and privatization facilitate the entry of new and small firms into markets that were previously protected and inaccessible.

(6) The increased importance of innovation in highwage countries has reduced the relative importance of large-scale production and instead fostered the importance of entrepreneurial activity.

With regard to the third hypothesis, women entrepreneurs have attracted increasing attention from authors in terms, for example, of the limitations of female-owned ventures (Menzies et al. 2004) or of the quality of family or personal lives (Morris et al. 2006). Brush (1992) pointed out that the similarities between the two sexes outweigh the differences, while du Rietz and Henrekson (2000) studied performance differences between ventures started by men versus women in terms of revenue growth.

Loveman and Sengenberger (1991) and Acs and Audretsch (1993) carried out systematic international studies examining the re-emergence of SMEs and entrepreneurship in North America and Europe. According to Audretsch and Thurik (2001), SMEs did not become obsolete as a result of globalization, but rather their role changed as the comparative advantage shifted towards knowledge-based economic activity (Smallbone and Rogut 2005; Nooteboom 2007). This has occurred for two reasons. First, large enterprises in traditional manufacturing industries have lost their competitiveness in producing in the high-cost domestic countries. Second, small entrepreneurial enterprises take on a new importance and value in a knowledge-based economy.

As Audretsch and Thurik (2001) stated, the new entrepreneurial economy was superior to the old managed economy. Initiatives such as the Global Entrepreneurship Monitor and policy initiatives are needed to move towards an entrepreneurial economy (Thurik and Wennekers 2004; Mas-Verdú 2007).
Consequently, one relevant aspect to consider is the support provided by public administration, via international initiatives, aimed at encouraging new SME (or even microfirm) creation through measures that include: simplifying administrative barriers and evaluating norms that hinder growth, taxation benefits, schemes for enhancing the entrepreneur's managerial skills, financial support, encouraging innovation, creativity (Fillis 2006) and technological capabilities, and instilling an entrepreneurial culture.

The articles offered in this issue summarize past efforts, introduce new perspectives, provide new empirical insights, and define future research needs on the globalization of entrepreneurship in small organizations. The collection of articles provides ample fodder for future inquiry on a topic of major theoretical and practical importance. The variety of topics addressed is designed to ensure interest for readers from across management and business. We hope to have achieved this goal with a collection of interesting, relevant contributions.

The paper of Lee et al. points to the fact that information technology (IT) has changed the way businesses operate and function in the networked global economy. While IT is no longer the domain of only large global corporations, small businesses lag behind their larger business counterparts primarily because of their inability or unwillingness to invest in IT. However, small firms, which are typically laborintensive, can increase productivity and provide value-added services to their customers based on advanced IT. This paper examines whether or not media selection and IT knowledge would contribute to the performance of small firms. The results of the study indicate that IT-related communication methods, such as self-service customer-center problem resolution, the instant help function, desk automation, and remote online trouble shooting, are becoming important for customer service performance. Also, individual IT knowledge has a significant effect on the process performance of small firms, while organizational IT knowledge has no such positive effect. Another important finding of the study is that small firms should make an effort to increase the application of IT communication methods, e.g., e-mail and Internet/EDI, to improve organizational performance. The results of the study shed some insightful light that could be helpful for small organizations to improve their organizational performance. 
Nowadays, the importance of entrepreneurship is widely recognized as a motor of both economic and social changes. Also, although formal institutions (such as regulations, procedures, labor markets, etc.) are very relevant in the new firm creation process, few studies specifically deal with the relationship between legal factors and entrepreneurship. In this context, the main purpose of Stephen et al.'s paper is to analyze the impact of enforcement practices (proxied by judicial formalism) and the regulation of working time on entrepreneurial activity by opportunity. The main findings of the research show that higher enforcement formalism mitigates the negative impact exerted by rigid working time regulations on the number of entrepreneurs. While it is agreed that regulatory rigidities may increase labor transaction costs, this paper shows that entrepreneurs are less sensitive to labor regulations the higher the level of enforcement formalism in which they operate is. Higher formalism is associated with lower enforcing efficiency and lower probability of being punished for transgressing laws. While in the paper we do not consider the convenience of alternative procedural models, we show that labor regulations, whatever their content, appear to have little effect on the decision to start a firm in highly formalist countries. We thus believe that earlier approaches to the impact of labor regulation on entrepreneurial activity wrongly assume that laws on the books are uniformly and effectively enforced across countries. A policy implication is that encouraging labor flexibility may not improve conditions for entrepreneurial activity in procedurally formalist countries. This is due to the fact that, in those countries, flexibility de facto characterizes employment relations, no matter what the law says.

The article on job satisfaction and commitment in the entrepreneurial SME by Akehurst et al. studies one relevant aspect for achieving improvement in productivity, namely, job satisfaction. The globalization process implies, among other things, that firms must be competitive if they want to introduce their products into markets and maintain their position. In this sense, it is necessary for them to adapt their production processes to the new climate, and one way of enabling this process is by promoting internal collective cooperation, on the basis that the joint effort of all organizational members is greater than the sum of its individual contributions. From this perspective, a new view considers that more incentives must be provided to teams, while reducing the role of the leader. Firms must enhance and encourage the talent and creativity of their employees and not depend solely on individual ingenuity. Therefore, the main task of the head of organizations is to create a favorable context for the development of internal collective cooperation, attempting to obtain new ideas and innovation from teams, not from individuals. The article by Akehurst et al. introduces the main elements of internal entrepreneurship and their influence, showing the elements that facilitate the appearance, existence, continuation, development, and promotion of the entrepreneurial spirit in the organizational team environment. In this sense, the authors test two hypotheses: they firstly contrast whether job satisfaction is directly and positively associated with the level of internal entrepreneurship and secondly whether the commitment of members to the team is directly and positively associated with the level of internal entrepreneurship. Both hypotheses are supported, and they have concluded that job satisfaction and commitment to the team are factors that have a direct and positive effect on internal entrepreneurship.

As Palacios-Marques et al. state in their paper, dynamic approaches from the Resource-Based View focus on explaining how distinctive competences are created, developed, and accumulated. This research tries to connect two key constructs, such as knowledge management and innovation-distinctive competences, distinguishing between Schumpeterian-distinctive competences and those of continuous improvement. Two dimensions have been considered in the knowledge management construct: principles and practices. It is useful to know if there is a commitment towards KM principles on the part of managers and if it is articulated across practices. Theoretical hypotheses are tested in two knowledgeintensive industries, such as the Spanish biotechnology and telecommunications industries, where knowledge and technological innovation are two successful factors. Moreover, the management of intangibles is more clearly appreciated than in other types of industry. They are dynamic industries characterized by technological discontinuity, where innovation (usually radical) is a fundamental aim, and the $R \& D$ effort is extremely high. The results of the empirical study show that introducing a KM program 
does not have a direct effect on firm performance, but must be considered as a mediating variable, such as innovation-distinctive competences. It is not possible to develop principles to manage and develop knowledge without the support of technological and organizational practices. A firm will successfully introduce KM programs if it is able to imbue $\mathrm{KM}$ principles and practices with processes, routines, and individuals, in order to increase its organizational memory and its ability to obtain, transfer, and apply knowledge. This research has also studied the relationship between two dimensions of innovationdistinctive competences. The effect of Schumpeterian-distinctive competences on continuous distinctive competences is stronger than the other way around, which shows the positive relationship between both dimensions of innovation-distinctive competences. It confirms that when a radical innovation is introduced into a firm, it results in other incremental innovations.

Despite the growing interest in both e-commerce and entrepreneurship as agents beneficial to generating personal income, reducing unemployment, and sustaining economic growth and wealth creation, there has been limited research on e-commerce entrepreneurs. The perceptions of Thai e-commerce entrepreneurs on factors considered critical to the success of their businesses are studied in the paper of Sebora et al. It is argued that these factors include characteristics of the e-commerce business founderachievement orientation, risk-taking propensity, e-networking skill, and locus of control-and factors linked to the firm's e-business service-reliability, responsiveness, ease of use, and self-service. Because of initiatives supporting e-commerce businesses in Thailand, governmental support is also examined. Business success is measured in terms of growth rate, sales volume, business stability, customer acceptance, and overall satisfaction of the e-commerce entrepreneurs. The study employs a cross-sectional survey design. The target population for the research is 1,544 Thai founders of e-commerce commerce businesses registered with the Thai Department of Business Development, Ministry of Commerce. From this population, 375 usable questionnaires, meeting the sampling criterion of operating for at least 2 years, are analyzed. Study results confirm that founder achievement orientation and locus of control are positively related to the competitive success of new, small, e-commerce businesses in Thailand. In addition, the results indicate that the reliability, responsiveness, ease of use, and self-service functions of e-service quality are positively related to the competitive success of these e-commerce operations. The conclusion of the study suggests that there are critical success factors by which e-commerce founders can contribute to business success, that e-commerce incubators should consider the development of e-service quality dimensions for competitive success, and that government agencies might focus their support in e-service areas where Thai e-commerce businesses might have a global competitive advantage.

The paper by Guzmán et al. addresses the relationship between economic growth and the quality of productive structure. This kind of "quality" is related not to activity sectors, but to an entrepreneurial set belonging to a particular territory. The qualitative evaluation of entrepreneurial structure includes wellknown characteristics, such as level of innovation, business collaboration, product quality, planning, internalization, and firm size. In addition, two new, original business characteristics are considered: productive dependence and functional dependence. Productive dependence represents the degree of concentration in relation to the number of suppliers on the one hand and to the number of clients on the other. Obviously, a high concentration level on inputs or outputs means a high vulnerability and, when this phenomenon extends through a large share of the entrepreneurial tissue, its "quality" is not high from a macroeconomic point of view. From a different perspective, functional dependence addresses the relationship among firms, not among sectors of activity, but considers the geographical origin of inputs-local, provincial, regional, national, or foreign markets-and the destination of outputs with the same geographical scale. Through elaborating a functional dependence index, it is possible to distinguish two kinds of firms that are important for a regional economic analysis: (1) "Market-maker" firms, which are basically focused on finding or broadening markets for products or services made in far-off territories, and (2) "Product-maker" firms, which are more specialized in selling their own products or services in foreign markets, with inputs coming from its local-regional market. Empirical analysis developed in two territories with different levels of development confirms, as do most relevant 
findings, that "Market-maker" SMEs are located predominantly in less developed areas, while "Product-maker" SMEs are basically located in more advanced territories.

The study by Robson et al. constitutes a significant contribution to the all too thin-on-the-ground research on entrepreneurship and, most interestingly, innovation in African countries. Studies such as these are vital in order to increase public awareness of the attempts that are being made in developing countries to foster innovation among new and existing firms, where, unlike their European counterparts, small firms receive little or no help in their striving towards change and progress. As these authors succinctly point out, despite government policy that has concentrated on larger firm development, in countries such as Ghana, SMEs are a vital way of alleviating poverty or reducing unemployment figures and represent the mainstay of any real attempts at developing the economy. The study uses data gathered directly from 496 entrepreneurs in Ghana in order to analyze innovative and entrepreneurial activity among a cross-section of firms from primary, secondary, and tertiary industries, thereby endowing it with a holistic perspective that has rarely been seen in relation to studies of African economies. The study raises important questions regarding entrepreneurship in developing countries, such as the link between social class and the access to secondary and further education, which, at least in this context, has both positive and negative connotations for entrepreneurial activity. Other concepts related to the nature of the firm, such as firm size, family ownership, or firm location, are also considered in terms of their effect on innovation. The multi-theoretical approach applied in this study is a useful example that could be applied to an enormous number of countries at a similar stage in their development and allows these authors to produce some interesting results and conclusions. Some basic societal weaknesses in areas that can be applied to a number of sub-Saharan countries are underlined in this study, which indicates that there is a whole wealth of talent that society is unwilling or unprepared to tap into at the present time. For example, doors must be opened for the female entrepreneur in Ghana and many countries like it in order for its innovation potential to be realized. This paper constitutes a useful guide to the progress being made in terms of innovation and the state of entrepreneurship in Ghana.

\section{References}

Acs, Z. J., \& Audretsch, D. B. (1990). Innovation and small firms. Cambridge, MA: MIT Press.

Acs, Z. J., \& Audretsch, D. B. (Eds.). (1993). Small firms and entrepreneurship: An east-west perspective. Cambridge, MA: Cambridge University Press.

Audretsch, D. B. (1995). Innovation and industry evolution. Cambridge, MA: MIT Press.

Audretsch, D. B. (2002). Entrepreneurship: A survey of the literature. European Commission, Brussels: Enterprise Directorate General.

Audretsch, D. B., \& Thurik, R. (2001). What's new about the new economy? From the managed to the entrepreneurial economy. Industrial and Corporate Change, 10(1), 267315.

Brock, W. A., \& Evans, D. S. (1989). Small business economics. Small Business Economics, 1, 7-20.

Brush, C. (1992). Research on women business owners: Past trends a new perspective and future directions. Entrepreneurship Theory and Practice, 16(4), 5-30.

du Rietz, A., \& Henrekson, M. (2000). Testing the female underperformance hypothesis. Small Business Economics, $14,1-10$.

Fillis, I. (2006). A bibliographical approach to researching entrepreneurship in the smaller firm. Management Decision, 44, 198-212.

Gomez-Casseres, B. (1997). Alliance strategies of small firms. Small Business Economics, 9, 33-44.

Jovanovic, B. (2001). New technology and the small firm. Small Business Economics, 16, 53-55.

Li, J., \& Matlay, H. (2006). Chinese entrepreneurship and small business development: An overview and research agenda. Journal of Small Business and Enterprise Development, 13, 248-262.

Loveman, G., \& Sengenberger, W. (1991). The re-emergence of small-scale production: An international perspective. Small Business Economics, 3, 1-38.

Mas-Verdú, F. (2007). Services and innovation systems: European models of technology centres. Service Business, $1,7-23$.

Mazzarol, T., \& Reboud, S. (2006). The strategic decision making of entrepreneurs within small high innovator firms. International Entrepreneurship and Management Journal, 2, 261-280.

Menzies, T., Diochon, M., \& Gasse, Y. (2004). Examining venture-related myths concerning women entrepreneurs. Journal of Developmental Entrepreneurship, 9(2), 89-97.

Morris, M. H., Myyasaki, N. N., Watters, C. E., \& Coombes, S. M. (2006). The dilemma of growth: Understanding venture size choices of women entrepreneurs. Journal of Small Business Management, 44, 221-244.

Nooteboom, B. (2007). Service value chains and effects of scale. Service Business, 1, 119-139. 
Scherer, F. M. (1988). Testimony before the subcommittee on monopolies and commercial law, Committee on the Judiciary, U.S. House of Representatives, February 24.

Smallbone, D., \& Rogut, A. (2005). The challenge facing SMEs in the EU's new member states. International Entrepreneurship and Management Journal, 1, 219-240.

Thurik, R., \& Wennekers, S. (2004). Entrepreneurship, small business and economic growth. Journal of Small Business and Enterprise Development, 11(1), 140-149.
Vernon, R. (1970). Organization as a scale factor in the growth of firms. In J. W. Markham \& G. F. Papanek (Eds.), Industrial organization and economic development (pp. 47-66). Boston: Houghton Mifflin.

Vesper, K. H. (1974). Entrepreneurship, a fast emerging area in management studies. Journal of Small Business Management, 12, 8-15. 